Portland State University

PDXScholar

\title{
Bleeding Albina: A History of Community Disinvestment, 1940-2000
}

\author{
Karen J. Gibson \\ Portland State University, gibsonk@pdx.edu
}

Follow this and additional works at: https://pdxscholar.library.pdx.edu/usp_fac

Part of the Race, Ethnicity and Post-Colonial Studies Commons, Social Justice Commons, and the Urban Studies and Planning Commons

\section{Let us know how access to this document benefits you.}

\section{Citation Details}

Gibson, K. J. (2007). Bleeding Albina: A history of community disinvestment, 1940-2000. Transforming Anthropology, 15(1), 3-25. https://doi.org/10.1525/tran.2007.15.1.03

This Article is brought to you for free and open access. It has been accepted for inclusion in Urban Studies and Planning Faculty Publications and Presentations by an authorized administrator of PDXScholar. Please contact us if we can make this document more accessible: pdxscholar@pdx.edu. 


\section{Karen J. Gibson}

\section{Bleeding Albina: A History of Community DisinVESTMENT, 1940-2000}

Portland, Oregon, is celebrated in the planning literature as one of the nation's most livable cities, yet there is very little scholarship on its small Black community. Using census data, oral histories, archival documents, and newspaper accounts, this study analyzes residential segregation and neighborhood disinvestment over a 60-year period. Without access to capital, housing conditions worsened to the point that abandonment became a major problem. By 1980, many of the conditions typically associated with large cities were present: high unemployment, poor schooling, and an underground economy that evolved into crack cocaine, gangs, and crime. Yet some neighborhood activists argued that the redlining, predatory lending, and housing speculation were worse threats to community viability. In the early 1990 s, the combination of low property values, renewed access to capital, and neighborhood reinvestment resulted in gentrification, displacement, and racial transition. Portland is an exemplar of an urban real estate phenomenon impacting Black communities across the nation.

KEYWORDS: community, segregation, disinvestment, gentrification, inequality

This was really part of much, much larger forces that are at work, and they may or may not be consciously malicious ... This is the result of city policy, of other kinds of large-scale things that systematically cripple or dismember a community. Some neighborhoods are "fed." Others are bled.

-Paul Bothwell, Boston Dudley Street neighborhood activist ${ }^{1}$

Karen J. Gibson is an associate professor of urban studies and planning at Portland State University. Her research interests concern racial economic inequality in the urban context, housing and urban policy, and the theory and practice of community development. She is interested in interdisciplinary approaches to understanding urban life, and applied research. She holds an M.S. in public management and policy from Carnegie Mellon University and a Ph.D. in city and regional planning from the University of California at Berkeley.
The preponderance of scholarship on Portland, Oregon, analyzes the city's achievements in various fields of urban and regional planning: land use, environment, transportation, central city revitalization, and civic involvement (Ozawa 2004; Abbott et al. 1994). Others debate the impact of the urban growth boundary, designed to limit sprawling development, on housing prices (Downs 2002; Fischel 2002; Howe 2004). However, very little scholarship analyzes the experience of Portland's Black community in this relatively remote Northwest city. Although the population is very small (never comprising more than 7 percent of the city and 1 percent of the state), Portland provides an interesting case study of a Black community that found itself suddenly in the path of urban redevelopment for "higher and better use" after years of disinvestment. The occupation of prime central city land in a region with an urban growth boundary and in a city aggressively seeking to capture population growth, coupled with an economic boom, resulted in very rapid gentrification and racial transition in the 1990s. As cities across the country increasingly seek to improve land values and woo the middle and upper classes back to the central cities as an economic development strategy, the fate of urban Black communities is uncertain. Local policy makers are grappling with ways to reduce the negative effects of sprawling development patterns, and the conversion of central city land into residential use offers a solution, especially as baby boomers and their children leave suburbia for compact inner-city living. It is critical to understand the links between the historical processes of urban development and contemporary forces that impinge on Black communities, so that central city residents might proactively engage with these forces. This work contributes to that effort by shedding light on the link between disinvestment and gentrification in Portland.

This is a case study analysis of the historical process of segregation and neighborhood disinvestment that preceded gentrification in Portland's Black community, Albina. Drawing upon various sources such as census data from 1940 to 2000, oral histories, archival documents, and news articles, it investigates the mechanisms that facilitated residential segregation and housing disinvestment. It also traces some of the Black resistance strategies to these mechanisms. Only after pressure from 
activists and the media did politicians, seeking votes, respond to the needs of Albina. The real estate industry (government housing officials, Realtors, bankers, appraisers, and landlords), by denying access to conventional mortgage loans, played a pivotal role in perpetuating the absentee ownership and predatory lending practices that fueled the decline in housing conditions. Many Black residents were denied the opportunity to own homes when they were affordable. Even after White flight from Albina in the 1950s and 1960s, Black home ownership continued to be restricted by discriminatory mortgage lending policies in the 1970s and 1980s, causing some to search elsewhere for ownership opportunities. During the 1990s, residential segregation between Blacks and Whites in Portland decreased so sharply that it ranked tenth nationally among metropolitan areas with the greatest declines (Frey and Meyers 2005). Ironically, although desegregation partly reflects the gradual opening up of the housing market, it also reflects the displacement of Black renters to suburban locations because of gentrification. In 2000, the African American home ownership rate in the city of Portland was just 38 percent, well below the national average of 46 percent. Recently the city, which has done a fairly good job of producing low-income housing, began trying to remedy the racial disparity in home ownership. While there are positive aspects to the revitalization of Albina neighborhoods, many Black residents wonder why it did not happen earlier, when it was their community. Portland is lauded for its livability—but livability for whom?

\section{RESIDENTIAL SEGREGATION AND HOUSING DISINVESTMENT PROCESSES}

The emergence of the black ghetto did not happen as a chance by-product of other socioeconomic processes. Rather, white Americans made a series of deliberate decisions to deny blacks access to urban housing markets and to reinforce spatial segregation. Through its actions and inactions, white America built and maintained the residential structure of the ghetto. ${ }^{2}$

Economic disinvestment - the sustained and systemic withdrawal of capital investment from the built environment - is central to any explanation of neighborhood decline. ${ }^{3}$

This study traces the simultaneous processes of racial residential segregation and disinvestment in Portland, Oregon. While the scale of segregation has been very small relative to large cities in the Midwest and Northeast, the consequences for residents are similar. Segregation is a tool of social and economic control that operates by confining Black citizens to a designated section of the city. Early sociologists labeled such areas the "Black Belt" or the "ghetto." Sociologist St. Clair Drake and anthropologist Horace Cayton were prescient in their analysis of the White rationale for segregation in their classic study of Chicago's South Side, Black Metropolis: A Study of Negro Life in a Northern City:

Midwest Metropolis seems to say: "Negroes have a right to live in the city, to compete for certain types of jobs, to vote, to use public accommodations - but they should have a community of their own. Perhaps they should not be segregated by law, but the city should make sure that most of them remain within a Black Belt.” As it becomes increasingly crowdedand "blighted"-Black Metropolis's reputation becomes ever more unsavory. The city assumes that any Negroes who move anywhere will become a focal point for another little Black Belt with a similar reputation. To allow the Black Belt to disintegrate would scatter the Negro population. To allow it to expand will tread on the toes of vested interests, large and small, in contiguous areas. To let it remain the same size means the continuous worsening of slum conditions there. To renovate it requires capital, but this is a poor investment. It is better business to hold the land for future business structures, or for the long-talkedof rebuilding of the Black Belt as a White officeworkers' neighborhood. The real-estate interests consistently oppose public housing within the Black Belt, which would drive rents down and interfere with the ultimate plan to make the Black Belt middle-class and White. [Drake and Cayton 1945:198, 211]

The mechanisms or "compulsions" by which cities across the United States ensured that Black people stayed in their place were articulated by housing scholar and advocate Charles Abrams (1955), in Forbidden Neighbors: A Study of Prejudice in Housing:

1. Physical compulsion through bombs, arson, threats, mobs

2. Structural controls such as walls, fences, dead-end streets

3. Social controls such as segregation in clubs, schools, and public facilities

4. Economic compulsions such as refusal to make mortgage loans, Realtors' codes of ethics, and restrictive covenants

5. Legalized compulsions that use the powers of government to control the movements of minorities such as condemnation powers, urban renewal, and slum clearance.

Various forms of these compulsions, including the physical threats such as cross-burnings, were used to restrict Black housing choice in Portland. Rose Helper, in her original book, Racial Policies and Practices of Real 
Estate Brokers (1969), details how Realtors used their "code of ethics" to put into practice the "racial real estate ideology" that property values decline when Black people live in White neighborhoods. This was the official word of the American Institute of Real Estate Appraisers, which maintained that "the clash of nationalities with dissimilar cultures" contributed to the "destruction of value" (Helper 1969:201). Realtors, lenders, and government guarantors widely promoted the use of restrictive covenants (mutually agreed upon by builders, Realtors, bankers, appraisers, insurers, and residents) that forbade non-Whites to own property in specific areas. Residential segregation holds the power to mold, stigmatize, and harm the living environment of a people. This does not imply that "ghetto" residents are passive victims, or that they are pathological, as some strands of urban theory suggest.

Neighborhood disinvestment involves the systematic withdrawal of capital (the lifeblood of the housing market) and the neglect of public services such as schools; building, street, and park maintenance; garbage collection; and transportation. The classical ecology theories of Chicago School sociology explained neighborhood growth and decline as a natural life cycle that unfolded in stages: rural, residential development, full occupancy, downgrading, thinning out, and then either crash or renewal (Park et al. 1984). Downgrading is associated with the outflow of original residents and inflow of lower-income residents and often corresponds with racial segregation. The housing ages, rents fall, and often there is overcrowding that also hastens dilapidation of the stock. Residents move out (if they can), and the neighborhood becomes a slum. While this interpretation is helpful for understanding the stages of neighborhood change, it does not adequately explain why such changes occur, as it lacks a discussion of capital, space, race, class, and power.

Scholars with a more critical approach analyze neighborhood decline by emphasizing the profit-taking of Realtors, bankers, and speculators, which systematically reduces the worth or value of housing in a process called devalorization (N. Smith 1996). The devalorization cycle has five stages: new housing construction and first cycle of use, transition to landlord control, blockbusting, redlining, and abandonment. After new housing ages, owners move elsewhere, sometimes to avoid the cost of repair, and the neighborhood has more renters than owners. During the second stage, absentee landlords may choose to profit off of the rent and decide not to make repairs. Depending on the market, it may be economically rational to under-maintain the property. The transition to landlord control may or may not include the third stage, blockbusting, but often involves a process of racial succession, or rapid population turnover. Blockbusting is the process by which Realtors use the fear of racial turnover and property value decline to induce homeowners to sell at below-market prices. Then the Realtor sells the property at inflated prices to Black (or other) home buyers. The fourth stage is when banks redline the neighborhood; this reduces owner occupancy and often prevents absentee landlords from selling a property they no longer want to keep. At this point, home ownership rates decline, and the downward trajectory of dilapidation continues until the final stage: abandonment. This is often accompanied by arson as property owners seek to cash out through fire insurance. Gentrification is the recycling of a neighborhood up to the point at which property values are comparable to those in other neighborhoods. If a developer can purchase a structure in an area, rehabilitate it, make mortgage and interest payments, and still make a return on the sale of the renovated building, then that area is ripe for gentrification. The cost of mortgage money is an important economic factor affecting the feasibility of reinvestment. This process occurs at the level of the neighborhood, not individual structures, and requires the involvement of housing market actors at the institutional scale. It also involves redlining motivated by appraisals that devalue African American neighborhoods. When the public and private sectors make a decision to disinvest, it is essentially proclaiming an area unworthy and ensuring its decline. In this view, gentrification is not just a matter of individual preferences for older centrally located neighborhoods; it is a matter of financial and governmental decisions. When capital is withheld from certain areas, predatory lenders move in to fill the void.

Historian Kenneth Jackson (1985) described the federal role in urban disinvestment on a mass scale through housing and transportation policies that supported massive suburbanization after World War II. Inner-city neighborhoods were systematically deemed unworthy of federally insured home loans by real estate appraisers, because they were destined for decline by their heterogeneous populations and mixed land-use patterns (residential, commercial, and industrial). When the federal government took the lead in proclaiming older central-city neighborhoods ineligible for investment, local government and private sector actors followed. Jane Jacobs (1961), a fierce critic of urban redevelopment schemes, argued that the policy of denying loans to urban neighborhoods because they were declining was a self-fulfilling prophecy. Housing dilapidation and abandonment are key indicators of poverty concentration in "underclass" neighborhoods (Jargowsky and Bane 1991). Abandonment almost always occurs simultaneously with tax delinquency: defraying the tax burden is one way to milk a property (Sternlieb and Burchell 1973). Perhaps the absolute final method of cashing in on property is through purposeful arson for insurance 
payoffs. Arson was an almost nightly occurrence in the Dudley Street neighborhood of Roxbury in Boston, Massachusetts (Medoff and Sklar 1994).

In Portland, there is evidence supporting the notion that housing market actors helped sections of the Albina District reach an advanced stage of decay, making the area ripe for reinvestment. Critical to the process was the systematic denial of mortgage capital, which was justified by appraisals that devalued African American neighborhoods. In addition, predatory lenders, speculators, and slumlords played a strong role in keeping Albina residents from accumulating wealth through home ownership and, in some cases, cheated residents out of their equity investments and earnings. Since home ownership is the most common form of wealth, this helped to perpetuate economic inequality in Portland (Oliver and Shapiro 1997).

As the Portland economy rebounded from a recession during the early 1990s, Albina became ripe for gentrification. Gentrification involves reinvestment in housing and commercial buildings, as well as infrastructural amenities such as transportation, street trees, signage, and lighting. It includes the movement of higher-income residents into a neighborhood and often involves racial transition. It requires financial investment in the built environment until property values are comparable to those of other neighborhoods, and it is an institutional, rather than individual-scale, process (N. Smith 1996). In other words, it is not just a cultural or social phenomenon reflecting a lifestyle trend - it reflects systematic reinvestment by financial institutions and the public sector. In Portland, the Black community was destabilized by a systematic process of private sector disinvestment and public sector neglect. After the press publicized the discriminatory lending practices of Oregon bankers, the city put pressure on them to reverse their policy. Financing became available at the same time that the economy was improving. In addition, by the mid-1990s, several nonprofit housing organizations had helped to improve Albina neighborhoods by developing new housing and rehabilitating tax-foreclosed properties. Combined with more aggressive building code enforcement and the creation of a huge urban renewal district and light-rail project on Interstate Avenue, the area was primed for reinvestment. The gap between the value of properties and what they could potentially earn was large enough for speculators to line up to buy tax-foreclosed properties in Albina.

\section{THE ALBINA DISTRICT}

Oregon was a Klan state-it was as prejudiced as South Carolina, so there was very little difference other than geographic difference.

—Otto Rutherford, community leader, 1978
We were discussing at the [Portland] Realty Board recently the advisability of setting up certain districts for Negroes and orientals.

—Real Estate Training Manual, $1939^{4}$

Albina was a company town controlled by the Union Pacific Railroad before its 1891 annexation to Portland (MacColl 1979). This area is located within walking distance of Union Station, on the east side of the Willamette River. Since the vast majority of Blacks, prior to World War II, worked for the railroad as Pullman porters, those who stayed settled near the station. Before the Great Depression, there was a small Black community in northwest Portland, with Black-owned businesses such as cafés, barbershops, and the Golden West Hotel, but most did not survive the Depression. Around 1910, they were pushed out of that community to the east side, according to Eddie Watson, who said, "As the town began to grow they switched us out" (Watson 1976). Black Portlanders had built the Mt. Olivet Baptist Church in Albina at the turn of the century. Because they were such a tiny fraction of the city's population (less than 1 percent) and many lived scattered about, Black Portlanders often spent time together at church, one of the few social functions available. This small community was well educated and primarily middle class, and about half were homeowners. But by 1940, half of Black Portland was confined to the Williams Avenue area in Albina as a result of severe housing discrimination (Pearson 1996; McElderry 2001). Residential segregation reflected the prejudice and discrimination Black people in Oregon had faced for more than a century, both by custom and by law. The Oregon Donation Land Act of 1850 promised free land to White settlers only. Many of the settlers preferred this territory because slavery was not permitted by law, and therefore they would not face economic competition from slaveholders. In 1857, by popular vote, Oregon inserted an exclusion clause in the state constitution that made it illegal for Black people to remain in the state. This clause was not removed until 1926. Oregon was one of only six states that refused to ratify the 15th Amendment to the U.S. Constitution, which gave Black people the rights of American citizenship and Black men the right to vote (McLagan 1980).

The hostile racial attitude of White Oregonians manifested in Portland's built environment through real estate practices. In 1919, the Portland Realty Board adopted a rule declaring it unethical for an agent to sell property to either Negro or Chinese people in a White neighborhood. The Realtors felt that it was best to declare a section of the city for them so that the projected decrease in property values could be contained within limited spatial boundaries. Historian Stuart McElderry (2001) periodizes the process of "ghetto-building," finalized by 1960, in three phases: 1910 to 1940 , the 1940 s, and the 
1950s. First, between 1910 and 1940, more than half the Black population of 1,900 was squeezed into Albina by the real estate industry, local government, and private landlords, who restricted housing choice to an area two miles long and one mile wide in the Eliot neighborhood. The second phase occurred in the 1940s, when roughly 23,000 Black workers who migrated to Portland for work in the shipyards were restricted to segregated sections of defense housing developments in Vanport and Guild's Lake and to the Eliot and Boise neighborhoods in the Albina District. During the third phase, in the 1950s, when defense housing was demolished by flood and bulldozer, Blacks were funneled into the Albina District. (Vanport, the largest wartime development in the nation, was flooded when the dike holding back the Columbia River broke.) As Blacks moved in, Whites moved out. Between 1940 and 1960, the Black population in Albina grew dramatically, while the White population shrank significantly as more than 21,000 left for the suburbs or other Portland neighborhoods.

This study focuses on the neighborhoods in the Albina District that were at least 35 percent Black in 1970 (see Figure 1). The Albina District includes all or part of eight neighborhoods (ten census tracts) that form

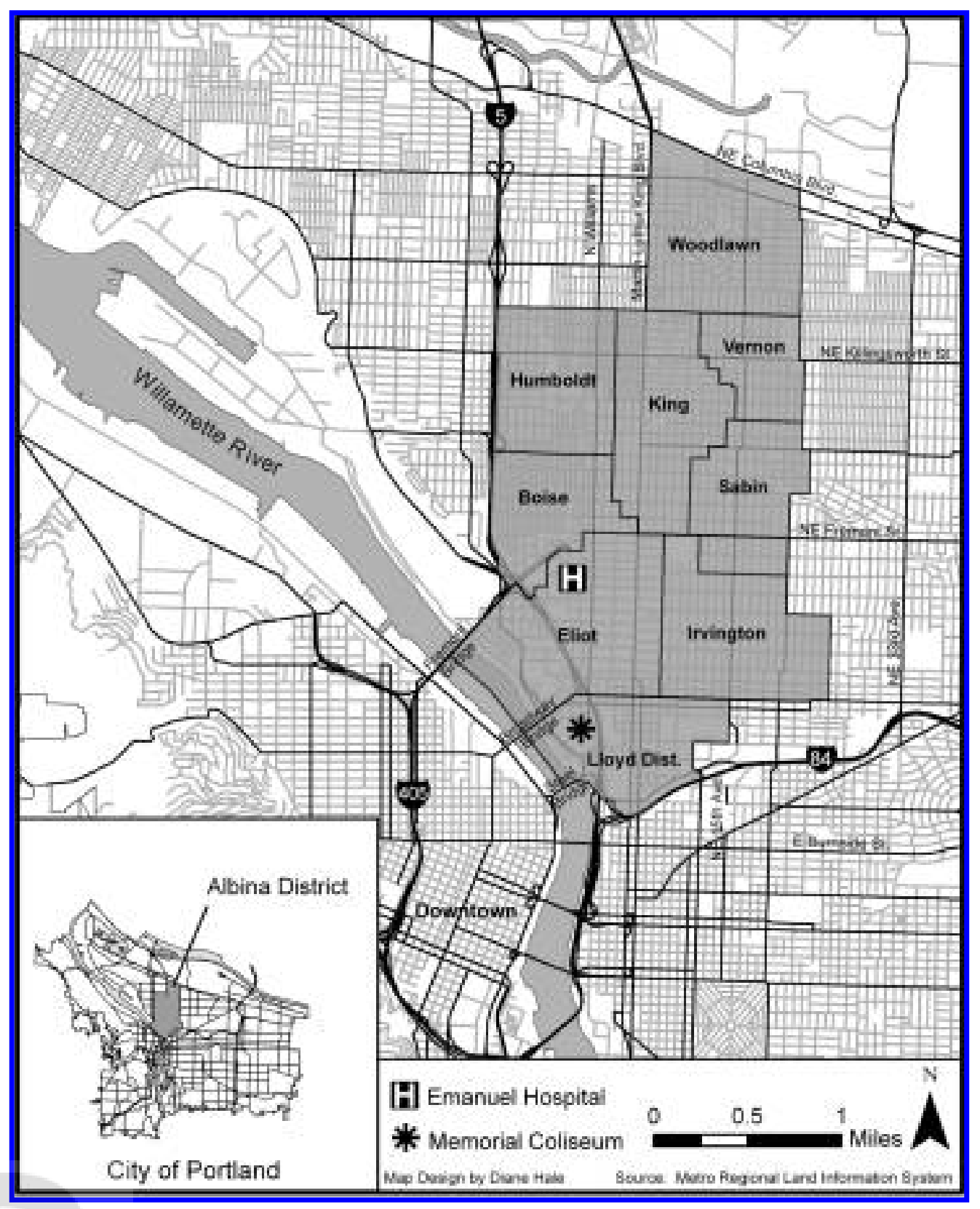

Figure 1. Albina District neighborhoods in Portland, Oregon. 
Table 1. Black population trends in Albina District neighborhoods, 1960-2000.

\begin{tabular}{|c|c|c|c|c|c|c|}
\hline & \multirow[b]{2}{*}{ Census Tracts } & \multicolumn{5}{|c|}{ Percent Black } \\
\hline & & 1960 & 1970 & 1980 & 1990 & 2000 \\
\hline \multicolumn{7}{|c|}{ Lower Albina } \\
\hline \multirow[t]{3}{*}{ Eliot } & 22.01 & 69 & 50 & 35 & 38 & 58 \\
\hline & 22.02 & 72 & 54 & 43 & 41 & 25 \\
\hline & 23.01 & 65 & 77 & 62 & 58 & 41 \\
\hline Irvington & 24.01 & 14 & 43 & 38 & 33 & 23 \\
\hline Lloyd & 23.02 & 54 & 45 & 28 & 25 & 20 \\
\hline \multicolumn{7}{|c|}{ Upper Albina } \\
\hline Boise & 34.02 & 67 & 84 & 73 & 70 & 50 \\
\hline Humboldt & 34.01 & 40 & 65 & 69 & 69 & 52 \\
\hline King & 33.01 & 21 & 61 & 63 & 63 & 54 \\
\hline King-Sabin & 33.02 & 31 & 62 & 64 & 58 & 43 \\
\hline Woodlawn & 36.01 & 12 & 36 & 49 & 62 & 51 \\
\hline
\end{tabular}

Note: Bold figures indicate when the Black percentage peaked. Irvington refers to western half of the neighborhood. Only a small part of Sabin is within the eastern census boundary at NE 15th Avenue, and a tiny portion of the Vernon neighborhood is in the study area, so it is not included.

Source: Author's calculations from United States Census Bureau Decennial Census, Summary File 3.

Lower and Upper Albina, which are distinguished both by their location (south or north of Fremont Street) and by the point in time that each was the center of the Black community. ${ }^{5}$ During the 1940 s and 1950 s, the Black community was centered in Lower Albina, which consists of three neighborhoods: Eliot, Irvington, and Lloyd. During the late 1960s and early 1970s, urban renewal and freeway construction forced residents to relocate northward, above Fremont Street, into Upper Albina. Upper Albina consists of five neighborhoods: Boise, Humboldt, King, Sabin, and Woodlawn. In the first period, the Eliot neighborhood was the focal point; in the 1970s it was succeeded by the King (formerly Highland) neighborhood, which remains the center to this day. Table 1 shows the point at which the Black population in each neighborhood peaked, as indicated by bold print. Note that Eliot was the largest neighborhood, both in population and geographic area, and it therefore consists of three census tracts. While Black residents comprised at least 43 percent of these neighborhoods at some point in the postwar period, Portland's Black population has never been greater than 7 percent, and Oregon's Black population has never been greater than 2 percent.

Although it is helpful to distinguish Lower and Upper Albina in order to understand the patterns of settlement and resettlement and the changing shape of the community, the name Albina is synonymous with the Black community in Portland. By 1960, four of five Black Portlanders lived in this 4.3-square-mile area, and by 1980 , despite the opening up of housing markets, one of two still did. By 2000, slightly fewer than one of three Black Portlanders lived there, and while many Black
Portlanders appreciate the physical improvements associated with the recent neighborhood revitalization, they also lament the loss of community that has come with it.

Of course it's nice and fixed up now, and the crime rate is down. We wouldn't want to have it the other way. But everyone wants home. Where is our place then? People know where they want to live if their culture is represented there. If a certain kind of person looks at Hawthorne, they know that's where they can be to feel comfortable. But our culture is scattered everywhere. It used to be that living "far out" was 15th and Fremont. Now it's 185th and Fremont. A lot of people leave the neighborhood because they feel they're leaving something that's not theirs anymore anyway. It will never be that way again. There's a lot of sadness. For a lot of us, it's just too hard to stay and watch your history erased progressively over time. There are just too many ghosts.

—Lisa Manning, Albina resident ${ }^{6}$

\section{ALBINA COMMUNITY FORMATION, 1940-1960}

At that time it was almost impossible to buy property anywhere other than around Williams Avenue ... Portland was really a very prejudiced city.

—Maude Young, 1976

The formation of the Black community in the Albina District was shaped by two major events: the labor migration during World War II and the 1948 flooding of Vanport City, the largest single wartime development in 
the United States and Oregon's second-largest city (Pancoast 1978). The migration, which temporarily created a tenfold increase in the Black population during the war years, meant that Portland had to face the question of housing. Although city leaders stubbornly resisted the development of any publicly subsidized housing, defense or otherwise, the attack on Pearl Harbor in December 1941 made it a patriotic duty to house defense workers, at least temporarily. Within a few months, "Magic Carpet Specials" brought the first trainloads of roughly 23 thousand African Americans and 100 thousand Whites, mostly from the South, to help with the Pacific war effort. Shipyards in Portland boomed with activity, as did five other major West Coast cities: Seattle, San Francisco, Oakland, Los Angeles, and San Diego. Black migrants came for the opportunity to work, and many chose to remain after war. The fact that more chose to leave Portland than any other West Coast city reflected its "national reputation among blacks of being the worst city on the West Coast, as bad as any place in the South" and dismal postwar employment prospects (Pancoast 1978:48; Taylor 1998). In Portland, after the war, there was little work, a housing shortage, and open hostility to the newcomers (both Black and White). The peak Black population in 1945, estimated at 23 thousand to 25 thousand, fell by more than half by 1950 . Table 2 shows that Portland's Black population was the smallest of the six coastal cities, both before and after the war. Meanwhile, Los Angeles and Seattle continued to attract migrants, and San Diego and San Francisco saw their populations increase modestly (Taylor 1998). A field report issued by the National Urban League, "The West Coast and the Negro," predicted that after the war, the region would have "a stranded population on its hands" because of employment and housing discrimination, as well as residency restrictions on relief assistance (Johnson 1944:22).

Black workers faced various forms of racial discrimination in both ship building (all cities except San Diego) and aircraft production (San Diego, Los Angeles, Seattle). In 1942, workers from New York City protested unequal working conditions at the Kaiser Company in Portland, claiming to have been recruited under the "false pretense" of equal rights to jobs and training (Pancoast 1978:41). The struggle for equal employment opportunity in West Coast shipyards lasted throughout the war. Black workers who refused to join the Boilermakers' segregated union auxiliaries were fired by the hundreds in Portland and Los Angeles. Forming groups such as the Shipyard Negro Organization for Victory (with 600 members in 1943), and organizing along with the NAACP, churches, Black newspapers, and other local leaders, those workers pressured the Federal Employment Practices Commission to rectify this indignity. Despite their efforts, the AFL Boilermakers Union, which covered two-thirds of all shipyard workers in the nation (6,600 in Portland and 7,200 in Los Angeles), never complied with the federal ruling to integrate the union locals (A. Smith and Taylor 1980).

Vanport is now housing many of the colored people. They will undoubtedly want to cling to those residences until they can get something better. No section of the city has yet been designated as a colored area which might attract them from Vanport.

-W. D. B. Dodson, Chamber of Commerce, $1945^{7}$

Housing was also a critical arena of racial conflict all along the West Coast, and defense housing, built with federal dollars, was little different. Black migrants were more likely to depend on public housing than were Whites, and "shipyard ghettos" were created in San Francisco, Los Angeles, Oakland, and Portland (Johnson 1944; Taylor 1998:268). During the 1940s, the Housing Authority of Portland (HAP) built and/or managed more defense housing than did any other city in the nation (18,000 units). Unlike Seattle's housing authority, which integrated defense housing, HAP restricted Black families to certain developments: the vast majority was housed in segregated sections of Vanport (6,000 residents) and Guild's Lake (5,000 residents), both of which were located outside of the city's residential areas. Vanport was hurriedly built in 1942-43 on marshland, and Guild's Lake was built on industrial land. After the Kaiser shipyards closed in 1945, many Black families who could not crowd into Albina, either due to lack of

Table 2. Black population growth in west coast cities, 1940-1950.

\begin{tabular}{lcccccc}
\hline & & & San & San & & \\
Year & Los Angeles & Oakland & Francisco & Diego & Seattle & Portland \\
\hline 1940 & 63,774 & 8,462 & 4,846 & 4,143 & 3,789 & 1,931 \\
1950 & 171,209 & 47,562 & 43,502 & 14,904 & 15,666 & 9,529 \\
\hline Percent Increase & $169 \%$ & $462 \%$ & $798 \%$ & $260 \%$ & $314 \%$ & $394 \%$ \\
\hline
\end{tabular}

Source: In Search of the Racial Frontier: African Americans in the American West, 1528-1990. Quintard Taylor, New York: W.W. Norton, 1998. 
resources or the inability to find housing, remained in Vanport and Guild's Lake. Comprising more than onethird of Vanport's population, Black residents organized the Vanport Tenants League to demand integrated housing and fair treatment from HAP and the police (McElderry 1998). HAP and city officials were eager to dismantle the town, calling it "troublesome" and "blighted" because of the racially mixed population and "crackerbox" housing construction (MacColl 1979:595). On Memorial Day 1948, a dike at the Columbia River broke and flooded Vanport. It killed 15 people and displaced more than 5,300 families, roughly 1,000 of them Black (McElderry 1998). Yet the flood that washed away Vanport did not solve the housing problem - it swept in the final phase of "ghetto building" in the central city.

After this disaster, thousands of residents lived in temporary trailers and barracks on the industrial land of Swan Island and Guild's Lake, some for as long as four years. Hundreds of Black and White families were stranded without employment or decent housing during this time. While there was some tension between the older Black residents and the newcomers, housing discrimination affected them both. During this decade, the pattern of racial transition in Albina neighborhoods that would last 50 years was first established: almost in checkerboard fashion, when Black residents settled in, White residents would move out. This pattern repeated itself within the eight neighborhoods of the Albina District until the early 1990s. Between 1940 and 1950, the entire Black population of Portland increased by 7,500 residents; about half of these crowded into the established Black community along Williams Avenue in Lower Albina. Whites migrated out, causing Blacks to increase proportionately to roughly one-third of the population. At this time, the Urban League of Portland, an interracial social agency, became active in improving employment and housing opportunities in Portland. In 1945, Dr. DeNorval Unthank, a physician and community leader, provided office space for Portland's new Urban League branch. Bill Berry, the first executive director, had been recruited from Chicago for a specific purpose, according to Shelly Hill, the League's first employment specialist: "The president of First National Bank, who was an Urban League member, told this new hire, "We need a good intelligent Negro to tell these people to go home."' But Berry responded that he had "the wrong person," because Berry's job was "to make Portland a place people can stay in" (Hill 1976).

\section{MAKING ALBINA HOME}

The flood washed out segregation in housing in Vanport. That is when the real estate board decided that it would sell housing to Negroes only between
Oregon Street which is the Steel Bridge and Russell from Union to the river. Later they expanded it to Fremont so they had no choice in buying a home; these were the only ones available.

-Shelly Hill, 1976

During the 1950s, Albina lost one-third of its population and experienced significant racial turnover as White residents left en masse for the suburbs and Black residents moved into Albina from temporary war housing. By decade's end, there were 23,000 fewer White and 7,300 more Black residents (total population was 31,510). Lower Albina grew from one-fifth to one-half Black, and Upper Albina increased from less than one20th to nearly one-third Black. As soon as it was politically feasible in the early 1950s, HAP closed the remaining Guild's Lake and Swan Island housing developments, where former shipyard workers still remained and Vanport residents had found shelter after the flood. HAP refused to provide any public housing alternatives, so Black residents were channeled and compressed into Albina. Despite the protests of concerned citizens, both Black and White, Portland, like other northern cities, responded to its growing Black population by confining them to "crowded, ancient, unhealthy and wholly inadequate" housing (City Club of Portland 1957:358). The City Club (a researchbased civic organization established in 1916), in its role as a watchdog over civic issues, reflects the progressive, reformist tradition of Portland's citizenry. The 1957 report "The Negro in Portland: A Progress Report, 1945-1957" documented what was generally understood: 90 percent of Realtors would not sell a home to a Negro in a White neighborhood. The report drew attention to the contradiction between the Oregon Apartment House Association's claim that 1,000 housing vacancies existed and the "known scarcity of apartment space for Negroes" (City Club of Portland 1957:361). Dr. Unthank, the only Black member of the City Club, who 20 years earlier had protested the lack of public housing alternatives which forced residents to live in substandard housing, criticized the reticence of HAP to build public housing in the face of a severe housing shortage. But HAP and Portland Realtors, like their national counterparts, had two major reasons for refusing to integrate neighborhoods. First, they maintained that because "Negroes depress property values," it was unethical to sell to them in a White neighborhood; and second, if they "sell to Negroes in White areas, their business will be hurt" (City Club of Portland 1957:359). In addition, citizens actively sought out restrictive covenants to prevent any nonWhites from buying homes in their neighborhoods. City planners tended to locate urban redevelopment 
projects in the neighborhood niches Blacks had established for themselves, causing residents great disruption and often relocating the same families more than once.

While racial discrimination was deeply institutionalized in a variety of arenas, Black Portlanders had a long history of fighting against it. After decades of struggle, the 1950s brought success in three areas: public accommodations, housing, and employment. Of West Coast cities, Portland was noted for its segregated restaurants, movie theaters, hotels, and amusement parks. Within three blocks of the Union Station, there were 13 signs that read "We cater to white trade only." Shelly Hill said, "The only way we got them down was by threatening them" (Hill 1976). Veterans returning from World War II broke out windows that displayed these signs, and the Negro Taxpayers' League organized to boycott those who would not serve them and frequent the places that would. The Portland branch of the NAACP, the oldest branch on the West Coast, had drafted the first public accommodations bill in 1919; the bill finally passed the legislature in 1953. Otto Rutherford, then president of the NAACP, said that there had to be "some funerals" before the bill could pass, meaning that members of the opposition literally had to grow old and die before they could get the needed votes (Tuttle 1990). Rutherford's parents had owned a café and barbershop in northwest Portland. He described one of the ways Blacks got around barriers to home ownership: since a 1926 state law said that "no Negro or Oriental could buy property," his "dad and uncle had a white attorney who would buy the property and sell it to them" (Rutherford 1978). In 1959, a Fair Housing Law that forbade discrimination in the sale, rental, or lease of housing passed the state legislature. In 1961, the League of Women Voters conducted a survey in integrated neighborhoods to evaluate the application of the Fair Housing Law. Black residents tended to be more educated than did their White neighbors. Four out of five said they had experienced housing discrimination. One Black family claimed that the inability to buy homes was compounded by employment discrimination: "There is a problem of fair and adequate employment . . . if there was adequate employment, a Negro could purchase the kind of house he wants" (League of Women Voters 1962).

In 1949, Oregon passed the Fair Employment Practices Act in response to pressure from a coalition of veterans, churches, and labor unions (Hill 1976). This act was an improvement over a previous version of the bill, which contained no enforcement provisions. During the 1950s, Shelly Hill, representing the Urban League, was instrumental in helping Blacks gain their first employment opportunities in state and local government, local newspapers, private companies, "the professions," and local colleges. The Urban League succeeded in getting more than 180 employers to hire Black workers. Portland's waterfront remained segregated until 1964, when the Longshoremen's and Warehousemen's Union accepted Black workers (Bosco-Milligan Foundation 1995).

Yet it was difficult for residents, regardless of race, to save their neighborhoods from the steady march of progress embodied in the urban renewal bulldozer. In cities across the nation, urban power brokers, with the help of the federal government, eagerly engaged in central-city revitalization after World War II. Luxury apartments, convention centers, sports arenas, hospitals, universities, and freeways were the land uses that reclaimed space occupied by relatively powerless residents in central cities, whether in immigrant White ethnic, Black, or skid row neighborhoods. In 1956, voters approved the construction of the Memorial Coliseum in the Eliot neighborhood, which destroyed commercial establishments and 476 homes, roughly half of them inhabited by African Americans. The Federal Aid Highway Act of 1956 made funds available to cities across the nation to whisk suburban residents to and fro. As a result, several hundred housing units were demolished in the Eliot neighborhood to make way for Interstate 5 and Highway 99, both running north/south through Albina. Displaced residents relocated in a northeasterly direction, above Fremont Street and toward Northeast 15th Avenue. Many crowded into older housing in the Boise and Humboldt neighborhoods, becoming more racially isolated from Whites. The Housing Act of 1957 gave cities the tools they needed to achieve the national goal of clearing slums, and local officials used them by systematically deeming Black neighborhoods "blighted" and in need of revitalization. Thus, not long after Black Portlanders got settled in Lower Albina, city leaders were making plans to convert the land, which was the heart of their community, into commercial, industrial, and institutional uses. The following statement, from Portland's application for federal urban renewal funds, is typical of the justifications for renewal employed by cities across the country:

There is little doubt that the greatest concentration of Portland's urban blight can be found in the Albina area encompassing the Emanuel Hospital. This area contains the highest concentration of low-income families and experiences the highest incidence rate of crime in the City of Portland. Approximately $75 \%$ to $80 \%$ of Portland's Negro population live within the area. The area contains a high percentage of substandard housing and a high rate of unemployment. Conditions will not 


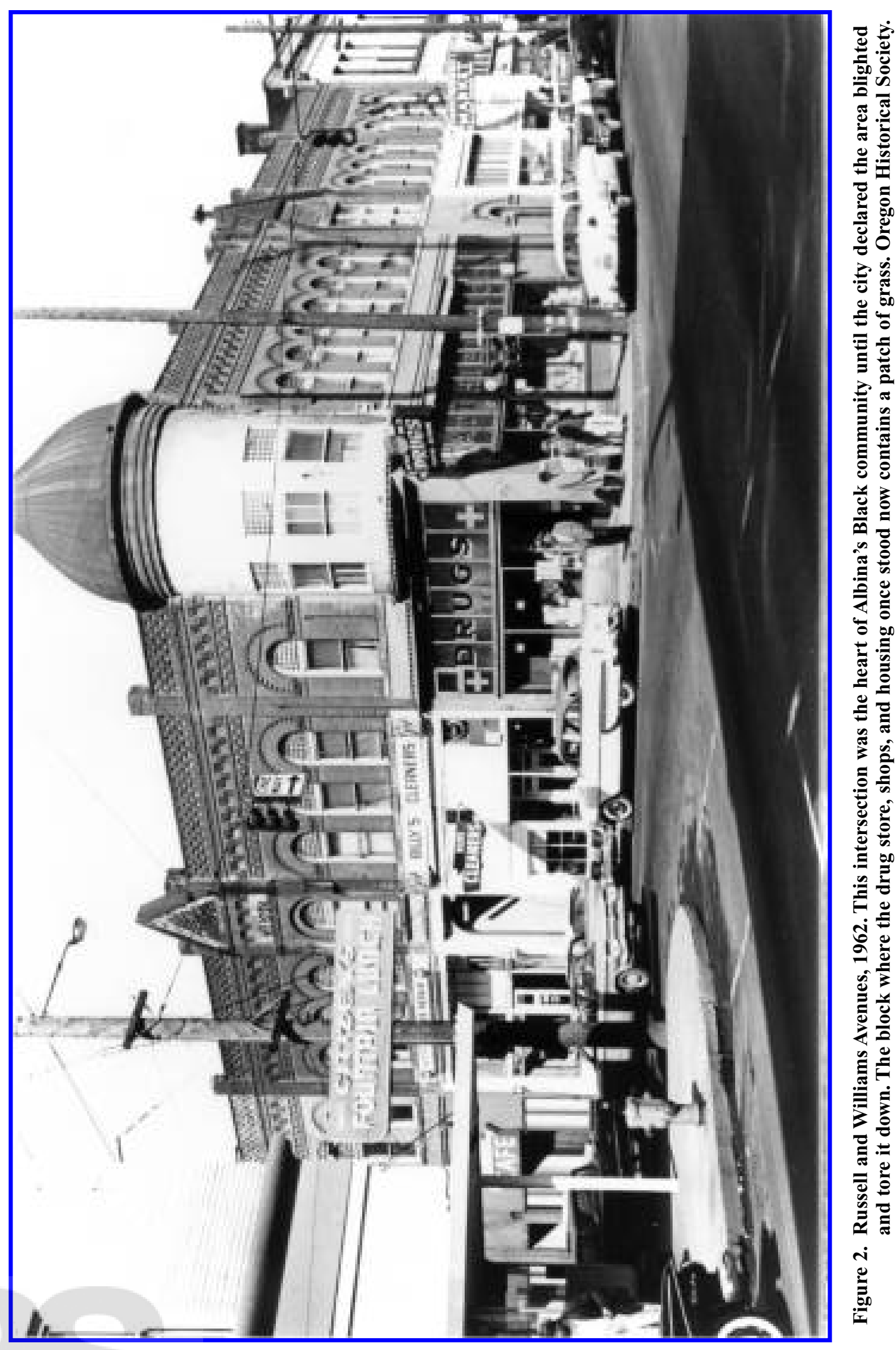


improve without a concerted effort by urban renewal action. The municipal goals as established by the Community Renewal Program for the City of Portland further stress the urgent need to arrest the advanced stages of blight. (Portland Development Commission 1966:17)

Albina residents organized, seeking to remedy the problem of aging and declining housing conditions through rehabilitation, not clearance. While they would have some success north of Fremont Street through the Albina Neighborhood Improvement Program (1961-73), Black residents would lose their own "Main Street" at the junction of Russell and Williams Avenues (see Figure 2).

\section{RESHAPING THE COMMUNITY, 1960-80}

When you get to feeling locked in - that's when the frustrations start.

-Frank Fair, Youth Worker, Church Community Action Program, 1967 (Bosco-Milligan

Foundation 1995:95)

[Albina] could be not only one of the most accessibly convenient areas of the city, but one of the most progressive and innovative neighborhoods as well. (City of Portland Model Cities 1969:2)

During the 1960s, Portland's African American population, although small relative to those in larger cities, was experiencing the same problems associated with racial discrimination and spatial segregation found elsewhere: high unemployment and occupational segregation, poverty, overcrowded and low-quality housing, segregated schools, and tension with police. It seems that the relationship between the Albina community and city agencies could be characterized by extremes of absolute neglect and active destruction. At times when residents resisted, they got some cooperation and support from the city, but ultimately they could not trust that it had their best interests at heart. Redevelopment policies were a source of deep conflict during the 1960s and 1970s. Albina's total population shrank by about 5,000, and neighborhoods experienced more racial transition, but this time most significantly in Upper Albina. Albina's White population dropped by nearly 8,000 residents, three-quarters from Upper Albina, as Black residents displaced from Lower Albina moved there. Some fled the area because of the increased anger of Black residents, which exploded into riots in 1967 and 1969. The Emanuel Hospital project, a classic top-down planning effort, destroyed the heart of the Black community in Lower Albina during the late 1960s, shifting and expanding it toward the northeast.
More than 11 hundred housing units were lost in Lower Albina, and the Black population in Eliot shrank by two-thirds. Businesses along Williams Avenue such as the Blessed Martin Day Nursery, the Chat and Chew Restaurant, and Charlene's Tot and Teen Shop (already relocated from the Coliseum area) were decimated to make way for the hospital (Bosco-Milligan Foundation 1995). By the end of the decade, the center of the Black community was relocated to a contiguous set of neighborhoods (King, Boise, and Humboldt) in an area of no more than two and a half square miles, bounded by Fremont and Killingsworth Avenues on the south and north and by Mississippi and Northeast 15th Avenues on the east and west. Martin Luther King Jr. Boulevard (formerly Union Avenue) ran straight up the middle, and the largest neighborhood, King, became the center. The Black presence had tripled in the Irvington, King, and Woodlawn neighborhoods, making Blacks the majority group in Albina. The Boise neighborhood was the most segregated: Black residents comprised 84 percent of its population, but just 6 percent of the city's total population. Among the six West Coast cities, segregation between Blacks and Whites in Portland was second only to that in Los Angeles (Sorensen and Taeuber 1975).

Black leaders, after their experience with urban renewal in the 1950s, devised strategies to protect, preserve, and enhance their neighborhoods. In 1960, Mayfield Webb, NAACP president and attorney, along with clergy and other activists, resisted the Central Albina Plan, a proposal to clear the entire area below Fremont Street from the interstate to Martin Luther King Jr. Boulevard (Bosco-Milligan Foundation 1995). They secured a commitment from the city to invest in housing and neighborhood improvements in the area above Fremont Street, where the Black home ownership rate was roughly 60 percent. The Albina Neighborhood Improvement Program (ANIP) brought neighbors together in a 35-block area, where they rehabilitated more than 300 homes and built a park named after Dr. Unthank (see Figure 3). Meanwhile, citizens petitioned the city to extend ANIP activities below Fremont Street and to change the city's plan to renew the area, but city commissioners refused. The Emanuel Hospital project was in motion and could not be stopped. The city expected to site a federally supported veterans' hospital there, and this justified clearance of a massive land area (76 acres). After the heart of the Black community was demolished, the federal project fell through, and large swaths of land lay vacant decades after the renovation of Emanuel Hospital. This was a particularly bitter pill to swallow for those who had seen the heart of their neighborhood destroyed. Jobs promised by the hospital never materialized (see Figure 4). During this decade, Eliot residents were also relocated for construction of 


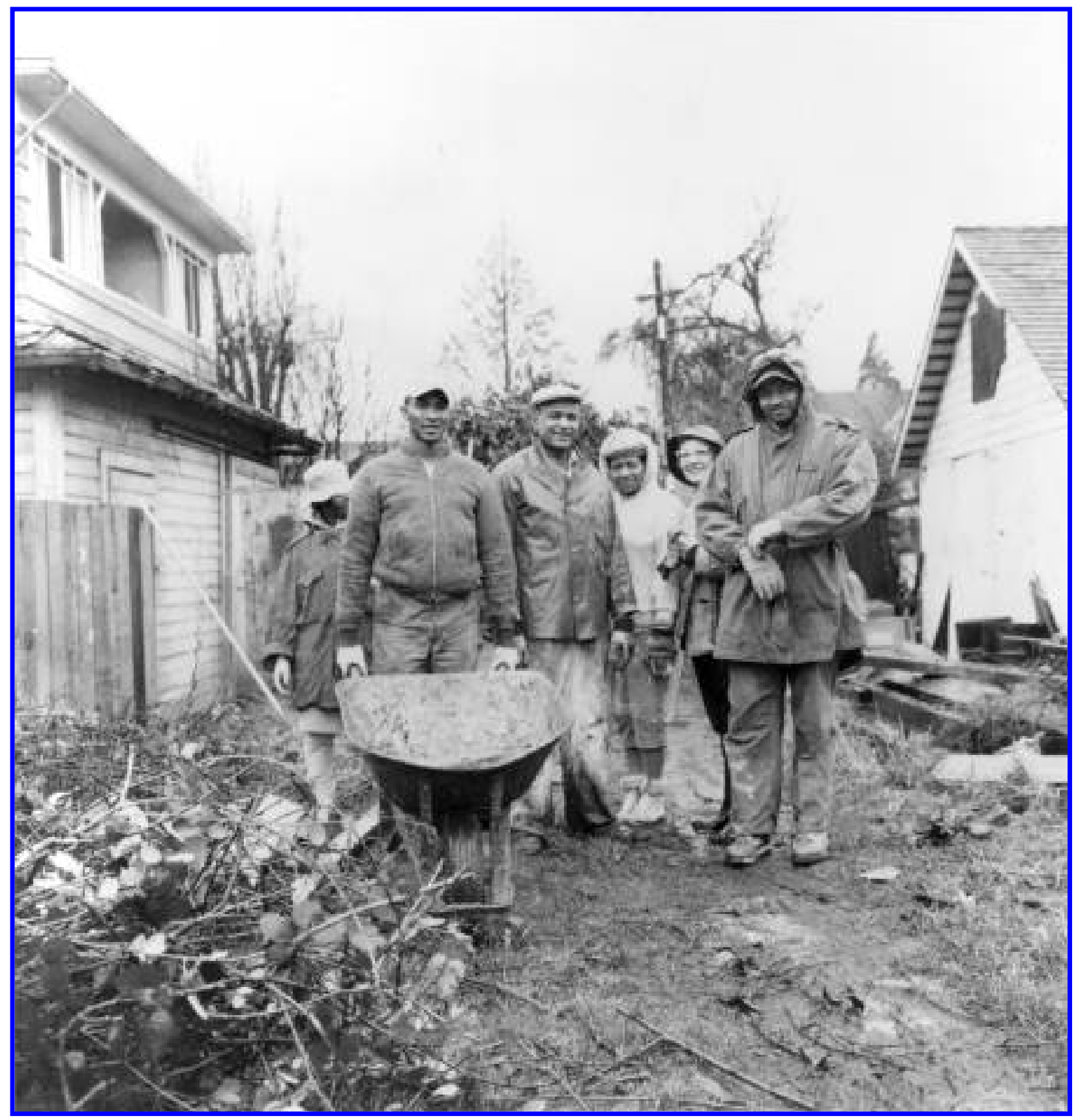

Figure 3. Neighborhood clean-up by the Albina Neighborhood Improvement Project, 1961-1973 pp. Oregon Historical Society.

the school district's central office and the city's water bureau. Nearly four decades later, a Black resident of gentrified Boise claimed that "a generation of black people" had grown up hearing the tale from their parents and grandparents of the "wicked White people who took away their neighborhoods" (Sanders 2005).

Urban renewal brutally disrupted various aspects of residents' lives: economic, social, psychological, spiritual. It disrupted their attachment to place and community. It forced them to start over, often without adequate compensation for their loss. By 1969, while middle- and working-class Blacks significantly increased the number of homes owned in Irvington, King, Sabin, and Woodlawn, the overall Albina home ownership rate declined from 57 percent to 46 percent. Urban renewal and unemployment (12 percent for males and 8 percent for females) were key factors in the declining home ownership rate, but the systematic refusal of banks to 


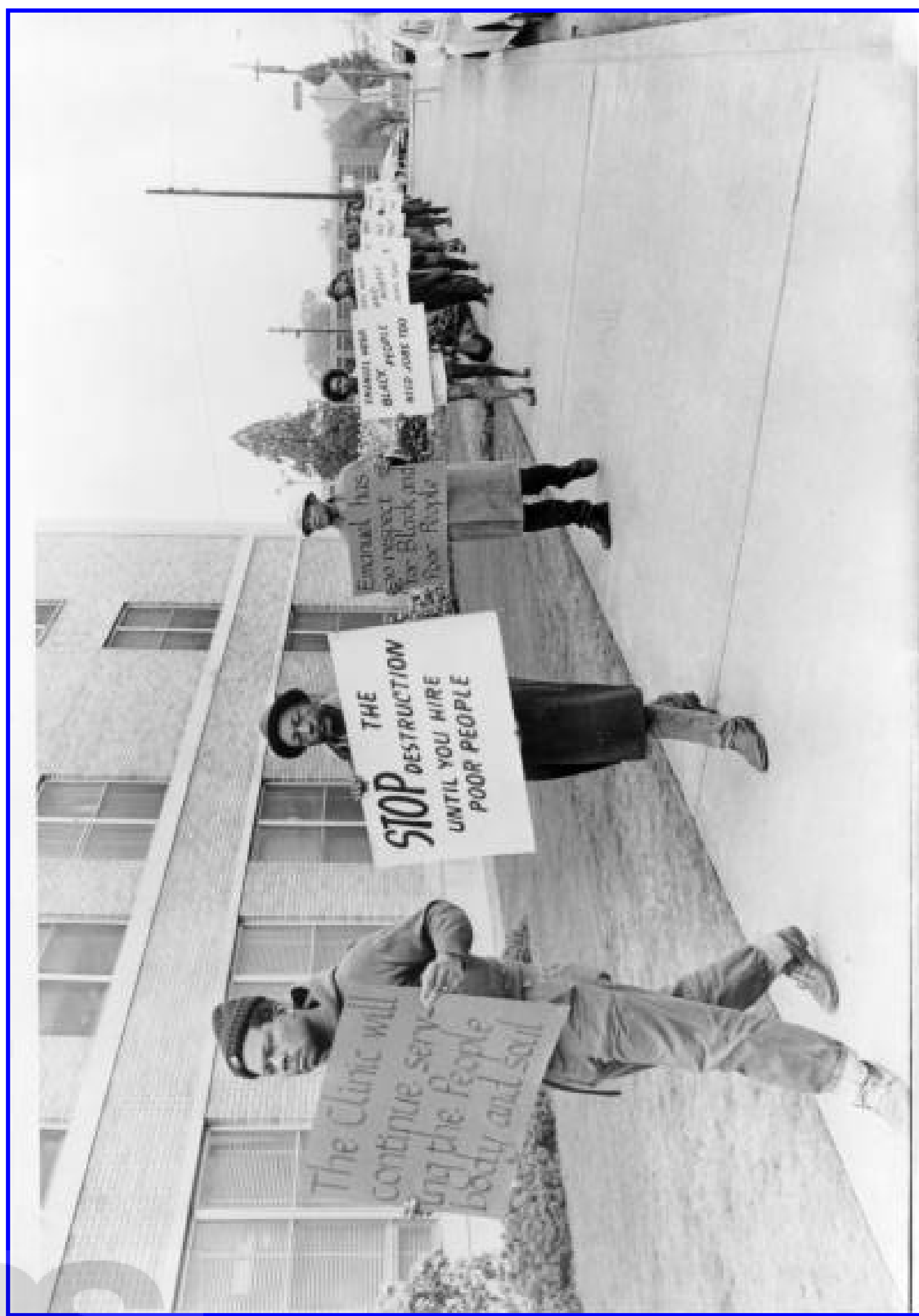

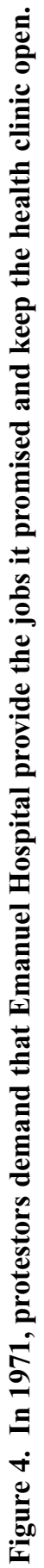


provide mortgage capital was a pivotal factor. It meant that prospective buyers could not buy and sellers could not sell, except if they lent the money themselves. Many in Albina, Black and White, purchased their homes "on contract" from the sellers. A 1969 housing survey concluded that "Blacks get bad terms in purchasing. They usually buy on contract paying $10 \%$ interest. It is difficult for them to get conventional financing. Selling prices are frequently inflated to black buyers" (Booth 1969:84). The inability to get capital to exchange homes or invest in improvements quickened the deterioration of the old, often overcrowded, housing stock. In recognition of the problem, a Black-administered bank, the Freedom Bank of Finance, opened in 1970. Venerable F. Booker, the bank president, was fully aware that the White bankers involved expected it to fail (Laquedem 2005). At that time, the median value of homes $(\$ 9,350)$ in Albina was just two-thirds the median value in the city of Portland.

The affluence of our nation during the 1960s, the civil rights movement, and civil unrest in urban areas led the federal government to sponsor a variety of community development initiatives such as the War on Poverty and Model Cities. Community action programs during the War on Poverty were designed to give money directly to neighborhoods that had been neglected by local governments. In 1964, Mayfield Webb directed a neighborhood services center funded by the War on Poverty, and a number of community action programs were developed in Albina at this time (Bosco-Milligan Foundation 1995). Of course, mayors across the nation were furious at the Johnson administration for circumventing their offices and empowering grassroots organizations. Model Cities was the federal response to the mayors' complaints. It still required citizen involvement in the form of "citizen planning boards," but mayors fought to retain authority over finance and projects. While the Portland Development Commission (PDC) had worked with Albina residents on the ANIP, it did not involve them in its initial 1967 application and planning for $\$ 15$ million in Model Cities money from the Department of Housing and Urban Development (HUD). HUD required public participation in Model Cities, and Portland's plan was criticized for merely "informing" rather than "involving" residents. In a revised plan that reached the city council in 1968, the PDC was "shocked" at resident perceptions of the problems in their neighborhoods, especially because they "spoke directly about racial discrimination." By 1969 , the PDC had taken an official position opposing the plan, in fear that the Citizens' Planning Board would assume the primary role in setting housing and development policy in northeast Portland. In fact, the PDC had kept plans for Emanuel Hospital "carefully reserved" from the Model Cities process "despite bitter opposition" (Abbott 1983:194-196). Charles Jordan became the fourth director of the Model Cities program. He later became the first Black city commissioner in Portland. While these two federal programs "did not solve the complex problems of Albina," they helped new Black leadership to emerge, and they focused attention on the problems of Albina (Bosco-Milligan Foundation 1995:93). However, a shortage of decent affordable housing, residential segregation, and unemployment remained vexing problems. While a variety of community-based initiatives began during this period, including the Albina Corporation (a job-training and manufacturing firm), the Albina Art Center, the Albina Youth Opportunity School, and the Black Educational Center, despite these efforts, some residents lost patience with the status quo.

Black youth in Albina, frustrated with being "locked in" and occupied by the police, exploded in riots in 1967 and 1969, accelerating White residential and business flight (City of Portland Planning Bureau 1991). Riots broke out in cities across the nation in the summer of 1967. A national commission was formed, the Kerner Commission, which studied the reasons for these violent explosions. The City Club of Portland (1968) issued a report entitled "Problems of Racial Justice in Portland" as a parallel to the national study. It concluded the following:

The range of deficiencies and grievances in Portland is similar to that found by the Kerner Commission to exist in large cities in general. It includes discrimination or inadequacies in many areas: in police attitudes and practices; in administration of justice; in unemployment and underemployment; in consumer treatment; in education and training; in recreation facilities and programs; in welfare and health; in housing and community facilities; in municipal services; in federal programs, and in the underlying attitudes and behavior of the White community. Thus Portland shares the common pressing problems and perils. To the extent that its problems differ from those of Watts, Newark, or Detroit, the differences are of degree, not of cause and effect, or urgency. [City Club of Portland 1968:9]

The report noted that racial residential patterns had resulted in racially isolated schools; specifically, four elementary schools were more than 90 percent Black (Boise, Eliot, Humboldt, and Highland [now named King]). Nearly half the Black children in Portland attended these schools. The report drew on analyses of housing conditions from Model Cities and mentioned two key elements usually associated with a systematic 
disinvestment process: absentee landlordism and mortgage redlining. These two operate in concert, as redlining prevents households from owning, and therefore they have little choice but to rent from absentee landlords who often neglect the property and charge high rent. The report also noted that substandard housing and negative environmental health conditions were pervasive in Albina and that these conditions and their alleviation were made more difficult by absentee ownership. Black homeowners with equity who wanted to move out of Albina faced discrimination in their attempts to buy in other neighborhoods or the suburbs, and those who stayed in the area had "more than normal difficulty in obtaining improvement or building loans" (City Club of Portland 1968). Speculation was noted as a problem as well in another Model Cities study, which found that housing investment in Albina was discouraged by the "speculative attitude of property owners," residents' "poor credit," and "builders' fear of militant actions" as a result of the civil unrest a few years earlier (City of Portland Model Cities 1971:4).

The City Club's Racial Justice Report urged the city to "overcome deficiencies in numbers of units and quality of available housing" and "review and reform building and sanitary codes, and their administration and enforcement, on an equitable, nondiscriminatory basis" (City Club of Portland 1968:52). It noted that Portland lagged behind other western cities with comparably sized Black populations in the development of public housing. Black residents, it argued, complained about the "scarcity" of brokers handling rental properties for African Americans. In some ways, the real estate industry had not changed its policies from the 1940smany brokers continued to discriminate for fear of losing "future business by dealing or listing with Negroes" (City Club of Portland 1968: 33-36). Despite community efforts, Albina was left to predatory lenders, speculators, and absentee landlords. The spiral of decline began to manifest itself in the form of dilapidated and abandoned housing, as Black residents began to relocate in better housing near Albina.

During the 1970s, African Americans across the nation saw improvements in their economic status as a result of the civil rights movement and affirmative action policies in education and employment. For the first time since the post-World War II period, the trend of Black population growth in Albina stopped as the housing market began to open up. Economic gains were manifested in the number of homeowners in Upper Albina, which by 1979 exceeded the number of White homeowners for the first time. Black residents had taken the opportunity to buy new homes in Woodlawn, where their home ownership rate was 56 percent, second only to Irvington at 81 percent. Their increased presence in Woodlawn caused many Whites to leave, making it the last Albina neighborhood to transition to majority Black. In Lower Albina, the reclamation of land for commercial and industrial use meant that the Black population in Eliot declined by 70 percent for the second decade in a row. The only significant Black presence was on the east side of Eliot and in Irvington. Home values in Albina remained just two-thirds of the city's median value, and while residents were able to achieve the rehabilitation of several hundreds of units as planned through the Model Cities process, this still fell short of the need (City of Portland Planning Bureau 1977). Although a late 1970s report by the PDC stated that the "problem of abandoned housing is a new area of concern for the City," the PDC would not seriously intervene until the problem hit crisis proportions in the late 1980s (Portland Development Commission 1978:18).

\section{THE ROAD TO ROCK BOTTOM, 1980-90}

You've got to be a real strong person to live here. If you have children, I'd advise against it.

—King resident, $1988^{7}$

One mortgage broker, Dominion Capital, Inc., has set up hundreds of home buyers in risky loans. The company's own principals said that they can make loans because they have little competition from conventional lenders. ${ }^{8}$

During the 1980s, disinvestment in the Albina area continued until problems became so severe that they finally became an issue for politicians in 1988. Economic stagnation, population loss, housing abandonment, crack cocaine, gang warfare, redlining, and speculation were all part of the scene. Neighborhood activists such as Edna Robertson, who worked in the Model Cities program and was the coordinator of the Northeast Coalition of Neighborhoods, had "raised warning flags about prostitution, drug dealing, abandoned housing and gang activity before they became public issues" (Oliver 1988). Gang members from the Los Angeles area had maintained a quiet presence in Albina since the early 1980s, but that changed during the summer of 1987, when competition intensified between the Crips and the Bloods over crack cocaine. Dozens of dealers from the Los Angeles area had begun streaming into Portland in search of new markets. It helped that they could sell crack for two to three times the price it fetched in southern California, and that the local police were unprepared for them (Ellis 1987).

Although 20 years earlier the City Club had criticized the city for its neglect of this area, an Oregonian journalist called Albina a "forgotten stepchild of city 


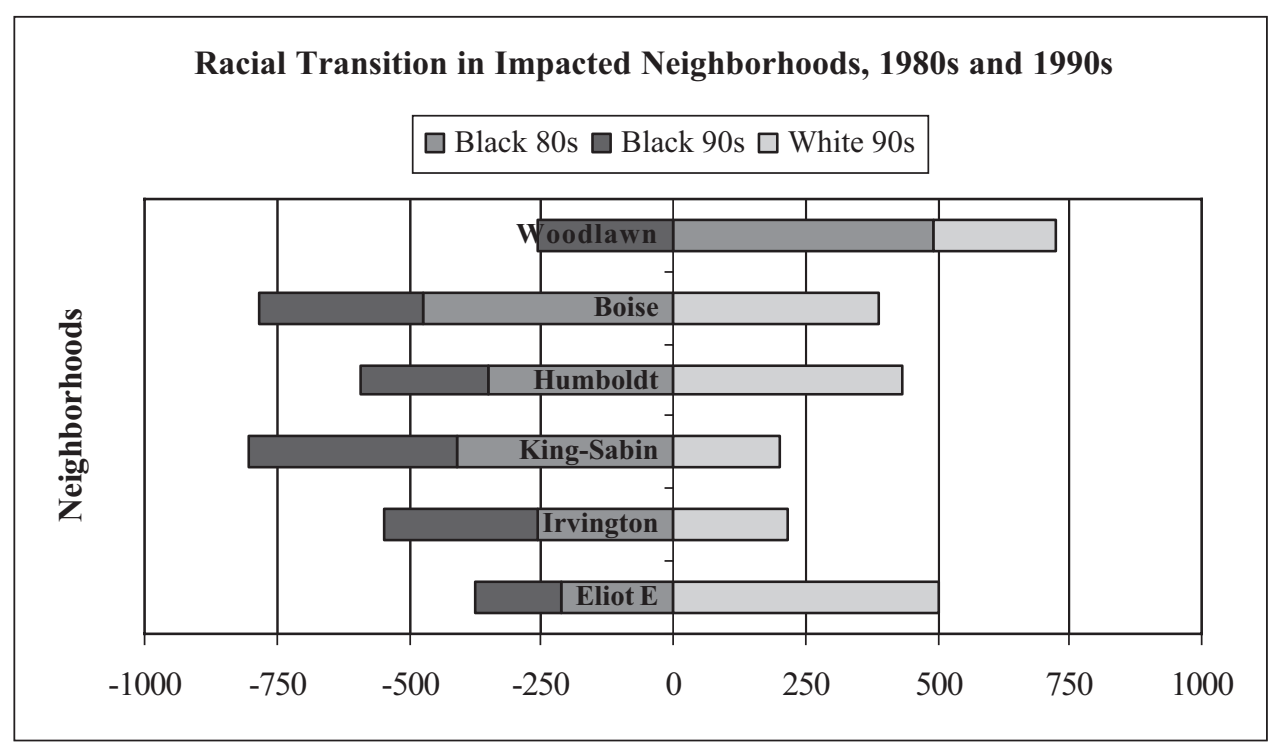

Figure 5. Number of people transitioning in and out of neighborhoods that experienced higher than normal population changes.

planning and economic development efforts" (Durbin 1988b). Black residents who could afford to move left the area, while those who could not stayed behind and lived with the consequences. During the 1980s, Irvington, King-Sabin, Humboldt, and Boise experienced significant declines in the Black population (see Figure 5). By the end of the decade, the proportion of Black Portlanders in Albina had shrunk by a more than a fifth, from 49 percent to 38 percent. The racial succession process that began in the 1940s finally came to an end, except in the Woodlawn neighborhood, where the Black population increased. Woodlawn borders the northernmost edge of the city, at the "dead end barrier" of the Columbia floodplain (Abbott 1985:6). The long process of moving the Black community northward, which began around 1910, as Eddie Watson said, when they were first "switched out" of northwest Portland, now culminated with residents at a physical dead end.

In terms of housing and neighborhood conditions, Albina hit rock bottom in the 1980s. The Albina population had thinned by nearly 27 thousand people since 1950. The value of homes dropped to 58 percent of the city's median. In fact, the decline was so sharp that nine neighborhoods received a special reassessment of property; some homes sold for half their assessed value. Absentee landlordism reached its height by 1989 , when only 44 percent of homes in Albina were owner occupied. The vast majority of the change in housing occupancy among Blacks in Upper Albina (96 percent) and Lower Albina (63 percent) represented Black owners selling homes. Some of this was due to generational change: many of the war migrants who came in the 1940s were now at the end of their lives, and their children had moved on. White homeowners also left in large numbers, especially in Upper Albina. The decline in population and owner occupancy can be explained by a number of factors. Certainly the economic stagnation that affected Albina beginning in the 1970s, and hit the entire state hard during the 1980s, explains part of it. The crack epidemic that devastated many communities nationwide also hit Portland in the mid-1980s. A recovering crack addict, Harrison Danley, compared the epidemic to the 1960s civil rights era: "We're not burning down houses now. We're burning down the fabric of our society" (Durbin 1988c). Gang shootings became more and more frequent from the middle to late 1980s. Drug dealing became a way for those out of work to make quick money, and the abandoned houses provided a place to both use and abuse. Houses would be stripped of any valuable materials by addicts or transients in need of money - doorknobs, light fixtures, wiring.

But the raiding of abandoned houses was only one type of plundering going on in Albina; other forces had been invisibly preying on the neighborhood for decades. Back in 1968, Black homeowners had complained about access to capital for home purchase and rehabilitation. In 1988, evidence of their complaints would come to light. The King and Boise neighborhoods, which comprised 1 percent of the city's land, contained 26 percent of the city's abandoned housing units. The banking industry had left a vacuum in the community when it decided not to lend money on properties below $\$ 40,000$. The rationale that the bank does not make money on small loans is a poor excuse for a policy of 
blatant discrimination against Black communities where property values are relatively low (Squires 1994). The only kinds of sales that occurred for years in Albina were through privately financed deals, often with terms considered predatory. As a Boston neighborhood activist articulated in this article's opening quotation, some neighborhoods are "fed," while others are "bled" (Medoff and Sklar 1994:33). Conventional bankers had effectively redlined Albina-bled the life out of it. This led to housing abandonment at a major scale. The worst neighborhoods were Boise, Eliot, and King, with more than 10 percent of the single-family homes vacant. Edna Robertson said that "absentee landlords were buying up houses as tax write-offs and putting no money into them" (Durbin 1988a). In 1988, she spent more than three months surveying 11 neighborhoods and counted a total of 900 abandoned buildings. This was the final stage of the devalorization cycle.

Activists such as Ron Herndon of the Black United Front had long urged the city to do something about rising crime and housing disinvestment, but their voices were not heard until the 1988 mayoral campaign of Bud Clark (Austin and Gilbert 1988). That same year, the Portland Organizing Project, an interracial faith-based alliance, began legal challenges against the lending practices of local banks, using the newly fortified Community Reinvestment Act. Eventually this issue caught the attention of the local newspaper. In September 1990, as a result of a three-month investigation into bank mortgage lending practices in northeast Portland, the Oregonian published a series of articles called "Blueprint for a Slum" (Lane and Mayes 1990). The series documented the lack of conventional mortgage loans and predatory lending practices in the Albina community. In 1987, all the banks and thrifts in Portland made just ten mortgage loans to a four-census tract area constituting the heart of the Albina community. The following year, they made nine loans. This was one-tenth the average number of loans per tract in the metropolitan area (Lane 1990b). This explained the flight of many Black middle-class households from the area. It also explained why predatory lenders and slumlords had come to fill the void left by conventional lenders. Lincoln Loan and Dominion Capital were two of the biggest companies "selling" homes to unaware consumers, using land sales contracts that kept real ownership in their hands. Lincoln Loan rented most of the 200 houses it owned in Albina but sold the ones that needed the most work to unsuspecting buyers (Mayes 1994). Lincoln Loan not only lent money to buy homes but also lent homeowners money to fix up the homes. When the owners wanted to cash out and move on, they would find out that they didn't really own the house after all. Dominion Capital owned more than 350 houses in inner northeast Portland and "sold" them to buyers, sometimes even when previous investors still had title. The scam worked as follows: Dominion would buy property at low prices, get phony appraisals that overvalued the property, and entice buyers into sales contracts with high-interest mortgage loans containing a balloon payment clause, which required that the mortgage be paid in full after a short period. Unsuspecting buyers who were unable to meet the balloon payment would be evicted. Dominion would then find another family to swindle. Shortly after "Blueprint for a Slum" ran in the paper, the state attorney general investigated Dominion, and the owners (one was named Cyril Worm) were sentenced to prison on 32 counts of fraud and racketeering. Albina had become a host for predators because of the void in conventional mortgage lending. Many neighborhood activists felt that these people had done more to hasten the deterioration of Albina than the crack dealers and gangbangers. Herndon, lamenting the decline in neighborhood stability that resulted from the departure of the Black middle class, pointed to the bankers: "Had they insisted that fairness be exercisedalmost single-handedly they could have stabilized that community a long time ago" (Lane 1990b). Yet the state had also failed to protect its consumers.

\section{RECLAMATION AND TRANSFORMATION, 1990-2000}

I can guarantee you they are paying more in rent than they would to buy a house in this neighborhood.

—Ora Hart, Realtor ${ }^{9}$

We fought like mad people to keep crime out of here. Had we not fought, I don't know what this area would've eventually been. But the newcomers haven't given us credit for it. I envisioned cleaning up the neighborhood, making the neighborhood livable for all of us. ... We never envisioned that the government would move in and mainly assist Whites. They came in to the area, younger Whites. [The Portland Development Commission] gave them business and home loans and grants, and made it comfortable and easy for them to come. I didn't envision that those young people would come in with what I perceive as an attitude. They didn't come in "We want to be a part of you." They came in with the idea, "We're here and we're in charge." ... In the past, Blacks and Whites worked very strongly together. We were one. This thing that happened in the last ten years has been most disappointing, most uncomfortable. It's like the revitalization of racism.

—Charles Ford, Boise resident since $1951^{10}$ 


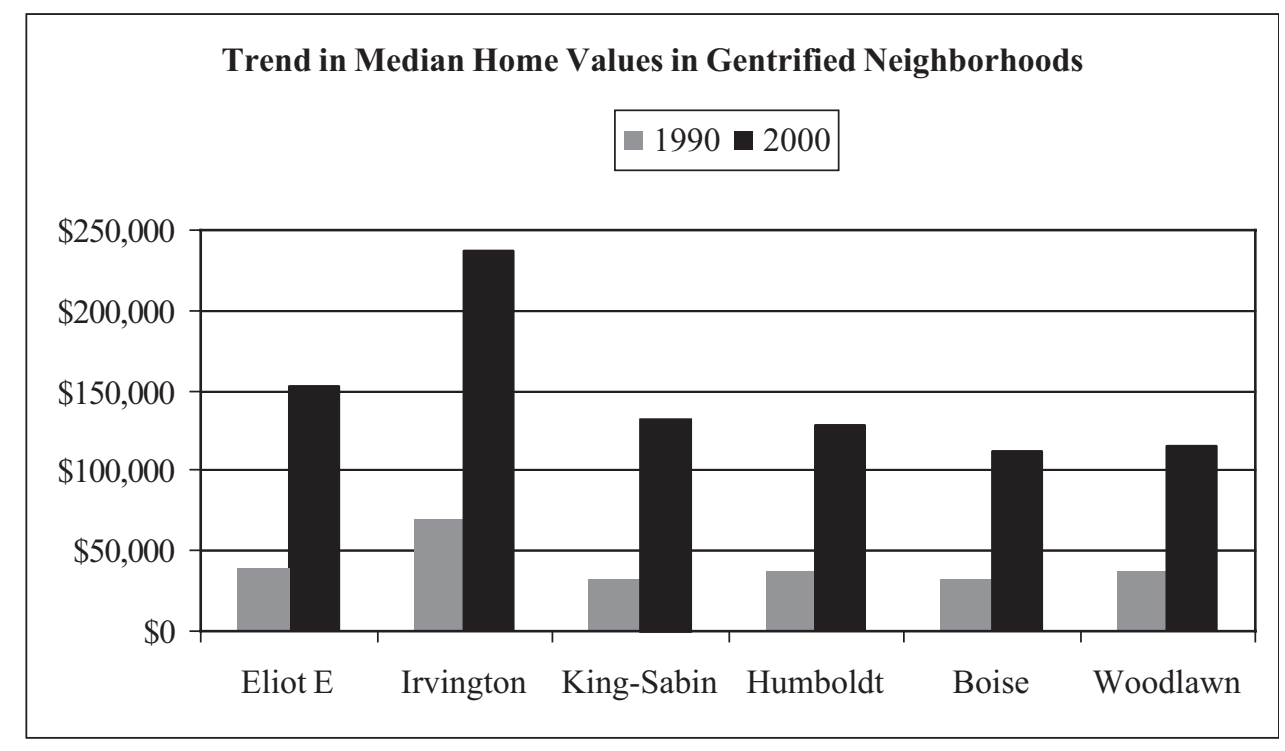

Figure 6. Home values tripled and sometimes quadrupled during the $1990 \mathrm{~s}$.

In the $1990 \mathrm{~s}$, for the first time in 50 years, the population of Albina grew. The pattern of racial transition was reversed, as Whites reclaimed the housing they had left decades earlier, enticed by the Victorian housing stock, affordable prices, and reinvestment efforts the city had been making. The same four areas Blacks left in significant numbers in the 1980s (Irvington, King-Sabin, Humboldt, and Boise) continued to experience a major decline in population. For the first time, too, Blacks left Woodlawn. Whites moved into these neighborhoods in greater-than-average numbers - and they finally stopped leaving Woodlawn (see Figure 5). And for the first time since 1960, Blacks were no longer a clear majority in any Albina neighborhood except on the northwest side of Eliot (an area that had lost 86 percent of its housing units since 1960 and had a tiny population of 200). Realtors used the art galleries popping up on Alberta Street, a Black business corridor, to aggressively market the King-Sabin area as the "Alberta Arts District," and it saw a rapid influx of White residents. Joe's Place, at 18th and Alberta, known in part for its great jukebox, was the last Black-owned bar on Alberta and one of the few remaining in Portland. Other clubs such as Marty's Place, Stax, The Silk Hat, and Theme closed down during the late 1980s and early 1990s. Other ethnic groups, largely Hispanics, increased their presence in Albina, and these changes meant that the overall racial and ethnic composition of Albina was transformed from Black majority to a three-way mixture, with no majority. These population trends explain the large decreases in segregation indices that ranked Portland in the top ten nationally. For the first time in 60 years, since the color line was hardened in 1940, segregation fell below a level considered high. At the turn of the century, less than one-third of Black Portlanders called Albina home.

During the 1990s, the City of Portland put concerted effort into the revitalization of Albina. In response to complaints of neighborhood activists and the recommendations of a citywide task force report on abandoned housing, the City began using building code enforcement to confront the extreme level of housing abandonment (City of Portland 1988). It gave more than 100 foreclosed homes to the Northeast Community Development Corporation for rehabilitation through the federal Nehemiah grant program. It stepped up Community Development Block Grant and other spending to support nonprofit housing development. It shamed the bankers, who had been redlining the community, into supporting the establishment of the Portland Housing Center to help boost home ownership among low-income households. It even set up a nonprofit community development corporation to take over Dominion's portfolio of 354 single-family homes.

Gretchen Kafoury, former state legislator and county commissioner, ran for city council on a housing platform and began work in 1991 at these activities. One of the White progressives who in the 1960s made her home in integrated Irvington, she never thought she would see an end to vacant and abandoned buildings in inner Northeast and North Portland "in her lifetime" (Kafoury 1998). But she has. Grassroots activists forced local government to stop the bleeding, but this turned the redlining to greenlining. Of course, the flood of White homebuyers would not have occurred without the 1990 s economic boom that raised home prices in all 
other quarters of the central city. A booming economy, cheap mortgage money, bargain-basement property, and pent-up demand coincided to transform pockets of Albina in three or four years from very affordable to out of reach. At the beginning of the decade, the worry was abandonment; at the end, it was the preservation of affordable housing.

By 1999, Blacks owned 36 percent fewer homes, while Whites had 43 percent more than a decade earlier. The decline was largely because Blacks sold their homes in Irvington, the most affluent neighborhood in Albina. Although overall the Black home ownership rate increased from 45 percent to 49 percent, it was because the proportion of Black renters declined. Whites bought homes, displacing many low-income folks to relatively far-flung areas where they could afford the rent. The White home ownership rate escalated from its rock bottom of 44 percent to 61 percent in just ten years. Housing values, as a percentage of the city median, rose significantly, from 58 percent to 71 percent (see Figure 6). This sharp rebound in Albina property values, which corresponds with the increase in White home ownership, reveals the continuing correlation between property valuation and race.

This was made starkly clear to Susan Hartnett, a White Chicago transplant who purchased a home in Eliot during the 1980s. Banks refused to lend to her because the mortgage amount was below their minimum, so she and her husband bought the $\$ 15,000$ home with savings. After using credit cards and pension funds to rehabilitate it, they tried again to get a mortgage, this time for $\$ 43,000$. When the loan officer and appraiser came out to inspect the home, the appraiser said it was a "nice place" that would appraise at a "much higher value in another neighborhood," but that he would have a hard time finding comparable sales. When Ms. Hartnett suggested other neighborhoods, the appraiser said "No, no, that would not work." Then the loan officer said, "It's because there are a lot more Blacks here than in those other neighborhoods." Ms. Hartnett was so surprised by the remark that she "nearly fell off the porch" (Lane 1990a).

\section{CONCLUDING REMARKS}

The larger community doesn't see a lot of value in this community - but before this crack epidemic you could walk into any part of inner-North and Northeast Portland anytime, anywhere.

\section{—James Mason, King resident ${ }^{11}$}

I am hurt, to the core. But I'm not mad. My hurt made me recognize the problems we had 40 years ago still exist. We thought that we had achieved.
We thought we'd bridged that. Little did we know-look at us today. We have to go back and start all over again.

—Charles Ford, Boise resident ${ }^{12}$

In the late 1980s, when Portland's Bureau of Buildings began to execute its charge from the council to "research and develop a range of proactive housing code enforcement programs," it met with neighborhood associations; city, state, and federal agencies; housing industry groups; and individuals (City of Portland Department of Public Safety 1989). The city faced strong opposition from industry groups such as the Oregon Apartment Association, Multifamily Housing Council, Board of Realtors, Institute for Real Estate Management, Oregon Mortgage Bankers Association, and the Association of Home Inspectors, which were concerned about the business impacts of the regulations and fees associated with code enforcement. After all, these entities had been operating virtually unrestricted for many years in a market they had captured for profit taking. Only investors could purchase homes for cash, since there was no conventional financing. One resident could borrow $\$ 25,000$ for a car but could not get $\$ 16,000$ for a house (Lane 1990b). Investors gobbled up properties at bargain rates, earning their money back with a few years of rental payments from low-income residents with few choices. Speculation and slumlordism flourished in this unregulated environment. One of the worst slumlords owned more than 100 houses and made a living renting to the poor and vulnerable (Kafoury 2005). Houses changed hands often, frequently with land-sales contracts that went unrecorded, making it difficult for the Bureau of Buildings to identify owners to make needed repairs. Houses would be milked for profits until they were abandoned. According to Margaret Mahoney, Bureau of Buildings director, most owners of abandoned houses were people she called "close absentee owners - people who live somewhere in the metropolitan area and own between 15 and 40 run-down houses that they bought cheap in the 1970s." Also according to Mahoney, some were "responsible property owners" who were just "exhausted" by the problems associated with gang and drug activity in the 1980s (Durbin 1988a).

Yet the degree of fraud and deception perpetrated on the people in Albina was remarkable: hundreds rented substandard housing, while others paid high rates and were swindled out of ownership through deceptive contracts. One couple took both mortgage and rehabilitation loans from Lincoln Loan, only to find out, when they tried to sell the home, that they did not own it. The City of Portland, when it finally got 
involved, implemented policies that transferred much of the housing into the hands of nonprofit housing agencies. It also targeted the top 12 offenders when it finally intervened on the issue of vacant housing (Kafoury 2005). The International City/County Management Association (ICMA) wrote a case study of Portland's policies for revitalizing vacant housing, declaring it a national model. Yet the case study does not discuss the racial transition, housing segregation, discrimination, redlining, property speculation, and government neglect that contributed to abandonment. It glosses over the tumultuous history of Albina, only referencing race as a "problem" for the community: "Racial tensions, which began in the 1960s and continued in the 1970s, further weakened the area, encouraging the flight of many remaining businesses" (ICMA 2002:27).

This investigation into Albina's past has revealed a much more complicated story behind its decline. It is important for the new homeowners of Albina to understand that some people paid a price to keep property values low. It is also important for policy makers to realize that home ownership, prior to the mid-1990s, was affordable to African American families; it just was not permitted or promoted. In the late 1990s, there was a flurry of government activity to help renters, most of them Black, being displaced from Albina. Ironically, this analysis reveals that an earlier intervention might have prevented homeowners from being displaced in the 1980 s, when many were virtually forced to leave to find mortgage capital and to escape gang warfare. But as James Mason said, the "larger community" did not "see a lot of value" in Albina neighborhoods. Albina residents did see value and fought to preserve their community. This is evident in the continuous thread of resistance dating from the 1930s, when Dr. DeNorval Unthank challenged city housing policies, to the late 1980s, when Edna Robertson counted the number of abandoned houses in several neighborhoods. Today, resistance against the impact of gentrification continues. Mr. Charles Ford is hurt, not angry, at what he calls "revitalized racism," yet he appears willing to "start all over again" to build interracial relationships. What this will portend for community viability and stable integration is a question for future analysis.

\section{NOTES}

1. Medoff and Sklar 1994:33.

2. Massey and Denton 1993:19.

3. N. Smith et al. 2001:498.

4. MacColl 1979:539-540.

5. The map in Figure 1 shows the neighborhood boundaries; these population and housing data are from the census tract boundaries, which are slightly narrower, with Mississippi and Albina Avenues on the west, and
Northeast 15 th Avenue on the east. Only a tiny portion of Vernon is in the study area, and, therefore, it is not mentioned in the article.

6. Chuang et al. 2005.

7. MacColl 1979:596.

8. Durbin 1988c.

9. Lane 1990b.

10. Lane 1990c.

11. Barnett 2005.

12. Durbin 1988c.

13. Barnett 2005.

\section{REFERENCES CITED}

Abbott, Carl

1983 Portland: Planning, Politics, and Growth in a Twentieth Century City. Lincoln: University of Nebraska Press.

1985 The Future of Neighborhood Integration. The Skanner, April 17: 6-8.

Abbott, Carl, Deborah Howe, and Sy Adler

1994 Planning the Oregon Way. Corvallis: Oregon State University Press.

Abrams, Charles

1955 Forbidden Neighbors: A Study of Prejudice in Housing. New York: Harper \& Brothers.

Austin, David, and Holley Gilbert

1988 Portland's Crack Alley. The Oregonian, August 3: $\mathrm{C} 1$.

Booth, Janet

1969 Housing Survey of the Portland-Vancouver Metropolitan Area. Portland, OR: Columbia Region Association of Governments.

Bosco-Milligan Foundation

1995 Cornerstones of Community: Buildings of Portland's African American History. Portland, OR: Author.

Chuang, Angie, Erin Hoover Barnett, Scott Learn, and Rob Finch

2005 The G Word; Here's What They Said. The Oregonian, May 26: 17.

City Club of Portland

1957 The Negro in Portland: A Progress Report 1945-1957. City Club of Portland Bulletin 37(46):355-370.

1968 Problems of Racial Justice in Portland. City Club of Portland Bulletin 49(2):3-65.

City of Portland

1988 Vacant and Abandoned Buildings Task Force Final Report. Portland, OR: Planning Bureau.

City of Portland Department of Public Safety

1989 Subject Memorandum: A Code Enforcement Plan for Vacant Buildings. Memo from Commissioner Dick Bogle, October 30. Portland, OR: Department of Public Safety. 
City of Portland Model Cities

1969 Consumer Protection, 3.185. Stanley Parr Archives, Box 6700-01, Folder 07/08/01. City of Portland Model Cities.

1971 Residential Development Program. Stanley Parr Archives, Box 6700-01, Folder 07/08/01.

City of Portland Planning Bureau

1977 Model Cities District Policy Plan. Portland, OR: Planning Bureau.

1991 Albina Community Plan Background Report, vol. 2: The Albina Community Neighborhoods. Portland, OR: Planning Bureau.

Downs, Anthony

2002 Have Housing Prices Risen Faster in Portland Than Elsewhere? Housing Policy Debate 12(1):7-31.

Drake, St. Clair, and Horace Cayton

1945 Black Metropolis: A Study of Negro Life in a Northern City. Rev. edition. Chicago: University of Chicago Press.

Durbin, Kathie

1988a Abandoned Houses Riddle NE Community. The Oregonian, August 1: B1.

1988b Convention Center Sparks Hope, Distrust. The Oregonian, December 23: A1.

1988c Crack Epidemic Devastates Portland's King Neighborhood. The Oregonian, July 31: A1.

Ellis, Barnes C.

1987 Ganging Up. The Oregonian, December 6: A1. Fischel, William

2002 Comment on Anthony Downs' "Have Housing Prices Risen Faster in Portland Than Elsewhere?" Housing Policy Debate 12(1): 43-50.

Frey, William H., and Dowell Meyers

2005 Racial Segregation in U.S. Metropolitan Areas and Cities, 1990-2000: Patterns, Trends, and Explanations. Research Report, 05-573. Lansing: Population Studies Center, University of Michigan.

Helper, Rose

1969 Racial Policies and Practices of Real Estate Brokers. Minneapolis: University of Minnesota Press.

Hill, E. Shelton

1976 Oral History Interview by L.A. Barrie. Neighborhood History Project (\#30, \#32). Sound Recording. Oregon Historical Society.

Howe, Deborah

2004 The Reality of Portland's Housing Market. In The Portland Edge: Challenges and Successes in Growing Communities. Connie P. Ozawa, ed. Washington, DC: Island Press.
International City/County Management Association

(ICMA)

2002 Portland, Oregon Vacant Properties Case Study. Electronic document, http://icma.org/ main/ld.asp?ldid=15072\&hsid=1\&tpid=17\&st id=93, accessed August 2005 .

Jackson, Kenneth

1985 Crabgrass Frontier: A History of Suburbanization in the United States. New York: Oxford University Press.

Jacobs, Jane

1961 The Death and Life of Great American Cities. New York: Random House.

Jargowsky, Paul A., and Mary Jo Bane

1991 Ghetto Poverty in the United States, 1970-1980. In The Urban Underclass. C. Jencks and P. E. Peterson, eds. Washington, DC: Brookings.

Johnson, Reginald A.

1944 The West Coast and the Negro. New York: National Urban League.

Kafoury, Gretchen

1998 Classroom discussion. School of Urban Studies and Planning, Portland State University. October 19.

2005 Interview with author. Portland, OR. August 18. Lane, Dee

1990a Buyers Say Home Loans Refused for Some NE Sites. The Oregonian, September 10: A11.

1990b Major Lenders Aid Decline of NE Portland. The Oregonian, September 10: A1.

1990c Neighborhood Activists Blame Blight on Lenders. The Oregonian, September 11: A1.

Lane, Dee, and Steven Mayes

1990 Consumers and State Misled. The Oregonian, September 9: A1.

Laquedem, Isaac

2005 Venerable F. Booker. Electronic document, http://isaac.blogs.com/isaac_laquedem/ 2005/02/venerable_f_boo.html, accessed August 2005.

League of Women Voters

1962 An Examination of the Attitudes, Policies and Procedures Which Affect the Application of the Oregon 1959 Fair Housing Law. Portland, OR: League of Women Voters.

MacColl, E. Kimbark

1979 The Growth of a City: Power and Politics in Portland, Oregon, 1915 to 1950. Portland: The Georgian Press.

Massey, Douglas, and Nancy J. Denton

1993 American Apartheid: Segregation and the Making of the Underclass. Boston: Harvard University Press. 
Mayes, Steven

1994 City Calls Company a "Slumlord." The Oregonian, February 11: F1.

McElderry, Stuart

1998 The Vanport Conspiracy Rumors and Social Relations in Wartime and Post-War Portland. Oregon Historical Society 99(2):134-163.

2001 Building a West Coast Ghetto: African-American Housing in Portland 1910-1960. Pacific Northwest Quarterly 92(3):137-148.

McLagan, Elizabeth

1980 A Peculiar Paradise: A History of Blacks in Oregon, 1788-1940. Portland, OR: Georgian Press.

Medoff, Peter, and Holly Sklar

1994 Streets of Hope: The Fall and Rise of an Urban Neighborhood. Boston: South End Press.

Oliver, Gordon

1988 "Mother of Black Community" Isn't Giving Up Hope. The Oregonian, August 15: C2.

Oliver, Melvin L., and Thomas M. Shapiro

1997 Black Wealth/White Wealth: A New Perspective on Racial Inequality. New York: Routledge.

Ozawa, Connie P.

2004 The Portland Edge: Challenges and Successes in Growing Communities. Washington: Island Press.

Pancoast, Diane L.

1978 Blacks in Oregon, 1940-1950. In Blacks in Oregon: A Statistical and Historical Report. William A. Little and James E. Weiss, eds. Portland, OR: Black Studies Center and Population Research and Census, Portland State University.

Park, Robert E., Ernest W. Burgess, and Roderick D. McKenzie

1984 The City. Chicago: University of Chicago Press.

Pearson, Rudy

1996 African-Americans in Portland, Oregon, 1940-1950. Work and Living Conditions: A Social History. Pullman: Washington State University.

Portland Development Commission

1966 Urban Renewal Grant Application to the Department of Housing and Urban Development. R103.

1978 Completing the 2nd Decade. Portland, OR.

Rutherford, Otto

1978 Oral History Interview by Helen Warbington and Elizabeth McLagan. March 3. (\#270). Sound Recording. Oregon Historical Society.

Sanders, Jacob Q.

2005 Rethinking Portland: One Neighborhood's Story. The Portland Tribune, November 11: 23.
Smith, Alonzo, and Quintard Taylor

1980 Racial Discrimination in the Workplace: A Study of Two West Coast Cities during the 1940s. Journal of Ethnic Studies 8(1):35-54.

Smith, Neil

1996 The New Urban Frontier: Gentrification and the Revanchist City. New York: Routledge.

Smith, Neil, Paul Caris, and Elvin Wyly

-2001 The "Camden Syndrome" and the Menace of Suburban Decline: Residential Disinvestment and Its Discontents in Camden County, New Jersey. Urban Affairs Review 36(4): 497-531.

Sorensen, Annemette, and Karl E. Taeuber

-1975 Indexes of Racial Residential Segregation for 109 cities in the United States, 1940 to 1970. Sociological Focus 8(2):125-142.

Squires, Gregory D.

1994 Capital and Communities in Black and White: The Intersections of Race, Class, and Uneven Development. Albany: SUNY Press.

Sternlieb, George, and Robert W. Burchell

1973 Residential Abandonment: The Tenement Landlord Revisited. New Brunswick: Rutgers Center for Urban Policy Research.

Taylor, Quintard

1998 In Search of the Racial Frontier: African Americans in the American West, 1528-1990. New York: W.W. Norton.

Tuttle, Jon

1990 Local Color. Documentary Film. Portland, OR: Oregon Public Broadcasting.

United States Bureau of Census

1940 Decennial Census. Ann Arbor: Inter-university Consortium for Political and Social Research [distributor].

1950 Decennial Census. Ann Arbor: Inter-university Consortium for Political and Social Research [distributor].

1960a Decennial Census. Ann Arbor: Inter-university Consortium for Political and Social Research [distributor].

1960b Table H1, Occupancy and Structural Characteristics of Housing Units, by Census Tracts. Portland, Oregon-Wash SMSA.

1970 Table H1, Occupancy, Utilization, and Financial Characteristics of Housing Units. Portland, Oregon-Wash SMSA.

1980 Table H1, Occupancy, Utilization, and Financial Characteristics of Housing Units. Portland, Oregon-Wash SMSA.

1990 Census. Summary Tape File 3A. Electronic document, http://factfinder.census.gov, accessed July 7, 2005. 
2000 Census. Summary Tape File 3. Electronic document, http://factfinder.census.gov, accessed July 8, 2005.

United States Bureau of Labor Statistics

1966 The Negro in the West: Some Facts Relating to Social and Economic Conditions. Washington, DC: Department of Labor.

Watson, Eddie

1976 Oral History Interview by Elizabeth McLagan, date unknown. (\#277) Oregon Black History Project. Sound Recording. Oregon Historical Society.

Young, Maude

1976 Oral History Interview by Elizabeth McLagan. July 21. (\#279) Oregon Black History Project. Sound Recording. Oregon Historical Society.

\section{ACKNOWLEDGEMENTS}

I wish to thank Leanne Serbulo, Bill Gibson, Karla Slocum, Lee D. Baker, Elvin Wyly, Peter Drier, Roman Cybriwsky, and the anonymous reviewers for their helpful comments. I also thank Jenny Bajwa and Irina Sharkova for their assistance with the historical census data. This research was partially supported by the Diversity Action Council and the Office of Research and Sponsored Projects at Portland State University. 